Fish \& Shellfish Immunology

April 2006; 20(4) : 536-547

http://dx.doi.org/10.1016/j.fsi.2005.07.003

(c) 2005 Elsevier Ltd All rights reserved
Archimer, archive institutionnelle de l'Ifremer http://www.ifremer.fr/docelec/

\title{
Effects of temperature and salinity on haemocyte activities of the Pacific oyster, Crassostrea gigas (Thunberg)
}

\author{
Beatrice Gagnaire $^{a}$, Heloise Frouin $^{a, b}$, Kevin Moreau $^{a}$, \\ Helene Thomas-Guyon ${ }^{\mathrm{b}}$ and Tristan Renault $\mathrm{t}^{\mathrm{a}}$
}

\author{
aLaboratoire de Génétique et Pathologie (LGP), Ronce-les-Bains, IFREMER La Tremblade, 17390 La Tremblade, \\ France \\ baboratoire de Biologie et Environnement Marin (LBEM), Université de La Rochelle, FRE 2727, Avenue Michel \\ Crépeau, 17042 La Rochelle, France \\ *: Corresponding author : Tel.: +33 54676 2649; fax: +33 54676 2611. trenault@ifremer.fr
}

\begin{abstract}
The Pacific oyster, Crassostrea gigas, is extensively cultivated and represents an important economic activity. Oysters are reared in estuarine areas, subjected to various biotic and abiotic factors. One of the limiting factors in aquaculture is mortality outbreaks, which may limit oyster production, and the causes of these outbreaks are not completely understood. In this context, the effects of temperature and salinity on Pacific oyster, C. gigas, haemocytes, were studied. Haemocytes are the invertebrate blood cells and thus have been shown to be involved in defence mechanisms. Flow cytometry was used for monitoring several haemocyte parameters. An increase of temperature induced an increase of haemocyte mortality, in both in vitro and in vivo experiments. Temperature modulated aminopeptidase activity. An in vitro decrease of salinity was associated with cell mortality. During the course of in vivo experiments, an increase of phagocytic activity was reported at $15 \%$ and 50\%. Environmental physical parameters may modulate haemocyte activities.
\end{abstract}

Keywords: Pacific oyster; Crassostrea gigas; Haemocyte; Temperature; Salinity; Flow cytometry; Cellular activity 


\section{Introduction}

Shellfish farming represents an important economic activity around the world. Among shellfish, the Pacific oyster, Crassostrea gigas, is the most cultivated species. In France, C. gigas was introduced in the 1970s to replace the Portuguese oyster, C. angulata (1). France ranks fourth worldwide in the production of C. gigas with 150000 tons produced annually. However, oyster production may be subjected to various limiting factors including mortality outbreaks. For several decades now, French Pacific oyster livestocks have presented abnormal mortality outbreaks during the summer period. This phenomenon called summer mortality has also been reported in North America and in Japan since the 1940s (2-4). Authors hypothesised that summer mortality outbreaks are the result of multiple factors, including elevated temperatures, physiological stress associated with sexual maturation, aquaculture practices, pathogens or pollutants (5). The Pacific oyster, C. gigas, is mostly reared in estuaries which are continually contaminated by pollutants (6). Estuaries are also subjected to important variations of abiotic environmental factors, including temperature and salinity. C. gigas is an osmo- and thermo-conformer species (7). In oysters natural habitat, salinity fluctuates with tidal cycles, rainfall and with drainage from adjacent terrestrial sites (8). In summer period, temperature can reach high values. Oysters are sessile benthic animals and as such are continually exposed to physico-chemical modifications of the environment. Physical stress such as tidal exposure, which modify temperature and salinity, can affect marine invertebrate defence mechanisms (9).

Bivalve defence mechanisms involve circulating blood cells, the so-called haemocytes (10). In C. gigas, two types of haemocytes can be differentiated on the basis of morphological features: hyalinocytes and granulocytes (10). Haemocytes constitute one of the main line of defence against non-self particles. They are involved in phagocytosis and encapsulation of foreign material (10-12). They also contain hydrolytic enzymes and produce reactive oxygen 
species (ROS), which play a key role in pathogen degradation (13-15). They have been used as immune capacity indicators in many bivalve species (16-19).

Studies have previously been conducted on the effects of temperature and salinity on bivalve haemocytes (20-23). Since bivalves are both osmo- and thermo-conformers, haemolymph readily acquires salinity and temperature of the external environment (7). In fact, haemocytes found in haemolymph and in tissue sinuses are exposed to temperature and salinity variations that occur in the environment. High water temperatures inhibit haemocyte spreading and locomotion in the eastern oyster, $C$. virginica (Gemlin) (24) while variations of temperature can also affect haemocyte counts and phagocytic activity in Ostrea edulis and Ruditapes philippinarum $(25,26)$. On the other hand, elevated salinity increased the time for spreading and reduced haemocytes locomotion towards target particles and may therefore pose an additional stress (27) and may also reduce oyster defence capacities and leave them more susceptible to parasites (27). Moreover, the susceptibility of $C$. virginica to the protozoan parasites Perkinsus marinus and Haplosporidium nelsoni is influenced by temperature and salinity $(24,28,29)$.

In this study, the effects of temperature and salinity on Pacific oyster, C. gigas, haemocyte parameters were investigated. Haemocytes were subjected in vitro to a range of temperatures and salinity. In vivo experiments were also carried out by placing oysters in waters at defined salinities or in incubators at controlled temperatures. Haemocyte parameters were monitored using flow cytometry. This emerging tool has often been used in marine bivalve research to describe haemocyte population characteristics $(30,31)$ or changes associated with pathology or environmental stress $(32,33)$. Cell mortality, esterase, aminopeptidase activities and phagocytic activity were monitored. 


\section{Material and Methods}

\section{Oysters}

Eighteen month-old Pacific oysters, C. gigas, 7-10 cm in shell length, were produced in the IFREMER hatchery in La Tremblade (Charente-Maritime, France). Temperature experiments were conducted in April and May 2002 and salinity experiments were undertaken in July 2004. For both experiments, oysters were held in tanks receiving a constant flow of external seawater.

\section{Haemocyte collection}

For temperature experiments, haemolymph was withdrawn from the pericardial cavity while for salinity experiments, haemolymph was collected from the posterior adductor muscle sinus. In both cases, a 1-mL syringe equipped with a needle $(0.9 \times 25 \mathrm{~mm})$ was used. Haemolymph samples were filtered on a $60 \mu \mathrm{m}$ mesh to eliminate debris and were maintained on ice to prevent aggregation. In order to reduce interindividual variation and to provide enough haemocytes for experiments, haemolymph samples were pooled.. Haemocytes counts were performed using a Malassez cell and the cell concentration was adjusted to $10^{6}$ cells per mL with artificial seawater (ASW: 23.4 g NaCl, 1.5 g KCl, 1.2 g $\mathrm{MgSO}_{4} 4 \mathrm{H}_{2} \mathrm{O}, 0.15$ g CaCl$_{2} 2$ $\mathrm{H}_{2} \mathrm{O}$, 0.1.5 g $\mathrm{CaCl}_{2}$ anhydrous; $\mathrm{H}_{2} \mathrm{O}$ qsp $\left.1 \mathrm{~L}\right)$.

\section{Effect of temperature on haemocyte parameters}

Before each experiments, the oysters were acclimated in tanks receiving external seawater (temperature and salinity were $11.6^{\circ} \mathrm{C}-17.7^{\circ} \mathrm{C}$ and $31.5 \%$-32.3 \%o).

\section{$\underline{\text { In vitro experiments }}$}

After collection of haemocytes and resuspension in ASW, antibiotics (kanamycin, erythromycin, oxolinic acid, $0.1 \mathrm{mg} \cdot \mathrm{mL}^{-1}$ ) were added. Haemocytes were incubated for $2 \mathrm{~h}$ 
and $4 \mathrm{~h}$ at varying temperatures $\left(4^{\circ} \mathrm{C}, 11^{\circ} \mathrm{C}, 20^{\circ} \mathrm{C}, 25^{\circ} \mathrm{C}, 35^{\circ} \mathrm{C}, 40^{\circ} \mathrm{C}, 50^{\circ} \mathrm{C}\right.$ and $\left.60^{\circ} \mathrm{C}\right)$. Cell mortality, phagocytic activity, esterase and aminopeptidase activities were monitored by flow cytometry as described below. Experiments were carried out in triplicates.

\section{$\underline{\text { In vivo experiments }}$}

Five oysters were emersed during 4 hours in incubators at different temperatures $\left(4^{\circ} \mathrm{C}, 11^{\circ} \mathrm{C}\right.$, $20^{\circ} \mathrm{C}, 25^{\circ} \mathrm{C}, 35^{\circ} \mathrm{C}, 40^{\circ} \mathrm{C}, 50^{\circ} \mathrm{C}$ and $60^{\circ} \mathrm{C}$ ). Haemolymphs were then withdrawn and pooled from five oysters without any treatment. Cell mortality, phagocytosis, esterase and aminopeptidase activities were analysed by flow cytometry as described below. Experiments were carried out in triplicates.

\section{Effect of salinity on haemocyte parameters}

Before each experiments, the oysters were acclimated in tanks receiving external seawater (temperature and salinity of external seawater were $18.7^{\circ} \mathrm{C}-19^{\circ} \mathrm{C}$ and $33.9 \%$ \%-34.5 \%o).

\section{$\underline{\text { In vitro experiments }}$}

After collection, haemocytes were divided into eight tubes, and centrifuged (10 min, $100 \mathrm{~g}$, $4^{\circ} \mathrm{C}$; Microfuge Beckman). The cells were resuspended in haemolymph only in tube 1 . The cells from tubes 2 to 7, were resuspended in a haemolymph-distilled water mixture in order to obtain a range of decreasing salinity (tube 2: $29 \%$, tube 3: $25.5 \%$, tube 4: $22.5 \%$ o, tube 5: $16 \%$, tube 6: $6.5 \%$, tube 7: $3 \%$ ). The cells from tube 8 were resuspended in distilled water (0\%).

Cell mortality was monitored using flow cytometry after $2 \mathrm{~h}$ and $18 \mathrm{~h}$ at $15^{\circ} \mathrm{C}$. Experiments were carried out four separate times. 


\section{$\underline{\text { In vivo experiments }}$}

In the first experiment, 40 oysters were placed in three tanks at 15 \% (hyposalinity), 35 \% (control) and 45 \%o (hypersalinity), respectively. Hyposalinity was obtained by mixing 25 L of seawater and $15 \mathrm{~L}$ of freshwater. Hypersalinity was obtained by the addition of $516 \mathrm{~g}$ of aquarium sea salts (Instant Ocean Aquarium Systems, synthetic sea salts without nitrate and phosphate, Haurit, Saintes, France) in $40 \mathrm{~L}$ of seawater. Oysters were fed with Chaetoceros gracialis $\left(3.10^{9}\right.$ cells per tank). Water and food were provided every day. Temperature of external seawater was maintained between $18.7^{\circ} \mathrm{C}-19^{\circ} \mathrm{C}$ during the experiments which lasted 7 days. Sampling of ten oysters per tank were then performed at day 1, 3 and 7. Ten oysters were also analysed at the beginning of the experiment. At each time, the oysters were divided in three pools. Cell mortality and phagocytosis were analysed by flow cytometry as described below.

A second experiment was conducted using the same protocol as previously described with the following differences: :oysters were maintained at 5 \% (hyposalinity), 35 \% (control) and 60 \%o (hypersalinity). Hyposalinity was obtained by mixing $35 \mathrm{~L}$ of freshwater and $5 \mathrm{~L}$ of seawater. Hypersalinity was obtained by adding 1219 g of aquarium sea salts (Instant Ocean Aquarium Systems, synthetic sea salts without nitrate and phosphate, Haurit, Saintes, France) in $40 \mathrm{~L}$ of seawater.

\section{Flow cytometry analysis}

The protocols used in the present study were previously described (34). For each sample, 3 000 events were counted using an EPICS XL 4 (Beckman Coulter). Results were depicted as cell cytograms indicating cell size (FSC value) and cell complexity (SSC value) and the fluorescence channel(s) corresponding to the marker used. Recorded fluorescence depended on the monitored parameters: enzymatic activities and phagocytosis were measured using 
green fluorescence while cell mortality was measured using red fluorescence. Mortality was quantified using $200 \mu \mathrm{L}$ of haemocyte suspension. Haemocytes were incubated in the dark for $30 \mathrm{~min}$ at $4^{\circ} \mathrm{C}$ with $10 \mu \mathrm{L}$ of propidium iodide (PI, $1.0 \mathrm{mg} \cdot \mathrm{L}^{-1}$, Interchim). Esterase and aminopeptidase activities were evaluated with commercial kits (Cell Probe ${ }^{\mathrm{TM}}$ Reagents, Beckman Coulter). Each analysis required $200 \mu \mathrm{L}$ of haemolymph and $20 \mu \mathrm{L}$ of the corresponding kit (FDA•Esterase and A•Aminopeptidase M). Haemocytes were incubated in the dark at ambient temperature $15 \mathrm{~min}$ for esterases and $30 \mathrm{~min}$ for aminopeptidases. Phagocytosis was measured by ingestion of fluorescent beads. Two hundred $\mu \mathrm{L}$ of haemocyte suspension were incubated $1 \mathrm{~h}$ in the dark at ambient temperature with $10 \mu \mathrm{L}$ of a $1 / 10$ dilution of Fluorospheres ${ }^{\circledR}$ carboxylate-modified microspheres (diameter $1 \mu \mathrm{m}$, Interchim).

\section{Statistical analysis}

Results were expressed as percentage of positive cells. In order to detected an effect of tested conditions, an ANOVA was performed using Statgraphics ${ }^{\circledR}$ Plus version 5.1 software. To ensure respect of a priori assumptions for normality and homogeneity, values were converted into $r$ angular arcsinus $\sqrt{ }$ (\% of positive cells) before analysis and .in the case of rejection of $\mathrm{H}_{0}$, an a posteriori test was used. Significance was concluded at $\mathrm{p} \leq 0.05$. 


\section{Results}

\section{Temperature effects}

\section{$\underline{\text { In vitro experiments }}$}

After a $2 \mathrm{~h}$ incubation period, cell mortality significantly increased at $40^{\circ} \mathrm{C}$ (Figure 1 , $\mathrm{p}<0.001$ ), while after a $4 \mathrm{~h}$ incubation period, mortality was significantly higher at $50^{\circ} \mathrm{C}$ and $60^{\circ} \mathrm{C}$ (Figure 1, $\mathrm{p}<0.001$ ). Percentages of aminopeptidase positive cells were significantly lower for both incubation periods at $50^{\circ} \mathrm{C}$ and $60^{\circ} \mathrm{C}$ (Figure 2). Percentages of esterase positive cells were significantly lower after a $2 \mathrm{~h}$ incubation period at $50^{\circ} \mathrm{C}$ and after a $4 \mathrm{~h}$ incubation period at $50^{\circ} \mathrm{C}$ and $60^{\circ} \mathrm{C}$ (Figure 3).

Figure 1: Haemocyte mortality percentage of oysters evaluated by flow cytometry after an in vitro $2 \mathrm{~h}$ or $4 \mathrm{~h}$ incubation period at several temperatures $\left(4^{\circ} \mathrm{C}, 11^{\circ} \mathrm{C}, 20^{\circ} \mathrm{C}, 25^{\circ} \mathrm{C}, 35^{\circ} \mathrm{C}, 40^{\circ} \mathrm{C}, 50^{\circ} \mathrm{C}\right.$ and $\left.60^{\circ} \mathrm{C}\right)$. Values are mean of three replicates. Bars represent standard deviation. ${ }^{* * *}: \mathrm{p}<0.001$.

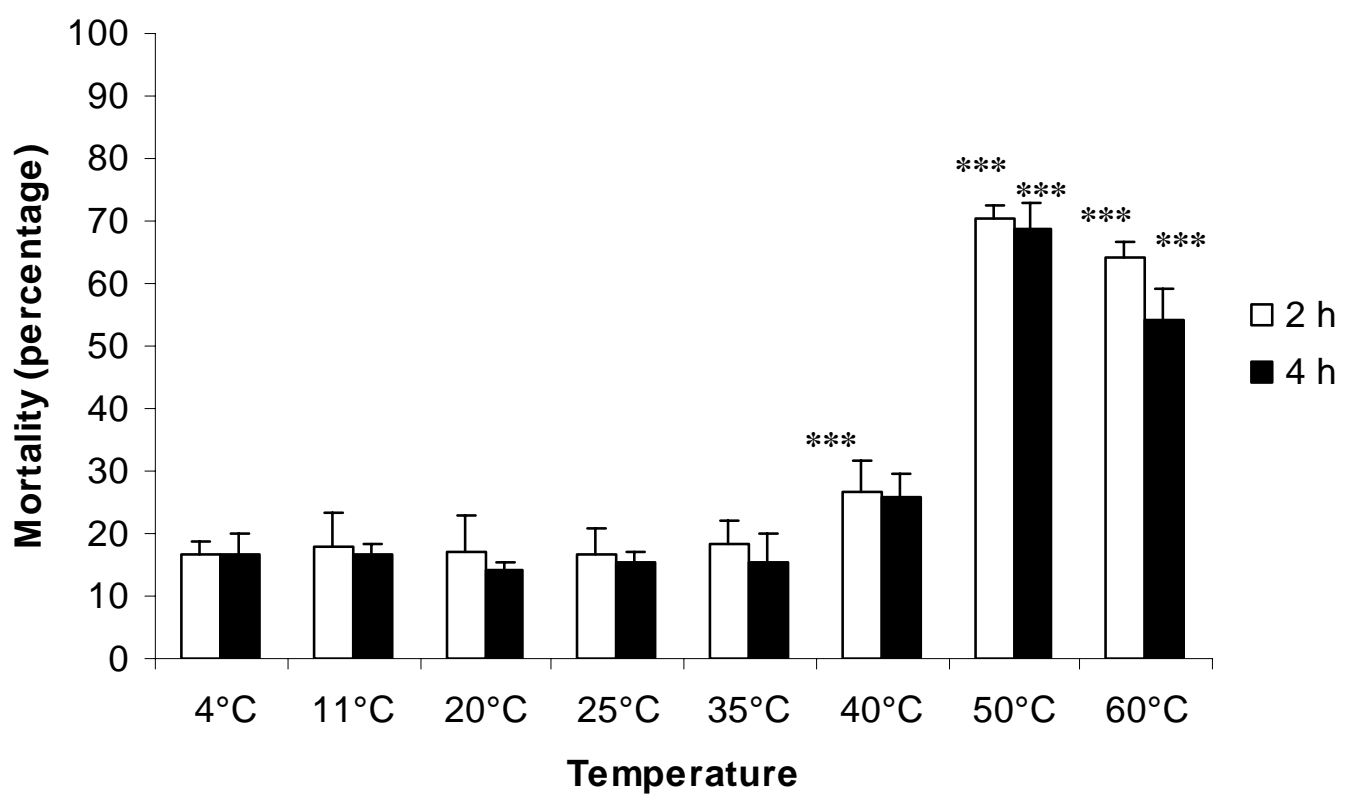


Figure 2: Percentage of positive cells for aminopeptidases of oysters evaluated by flow cytometry after an in vitro $2 \mathrm{~h}$ or $4 \mathrm{~h}$ incubation period at several temperatures $\left(4^{\circ} \mathrm{C}, 11^{\circ} \mathrm{C}, 20^{\circ} \mathrm{C}, 25^{\circ} \mathrm{C}, 35^{\circ} \mathrm{C}, 40^{\circ} \mathrm{C}, 50^{\circ} \mathrm{C}\right.$ and $\left.60^{\circ} \mathrm{C}\right)$. Values are mean of three replicates. Bars represent standard deviation. ${ }^{*}: \mathrm{p}<0.05,{ }^{* * *}: \mathrm{p}<0.001$.

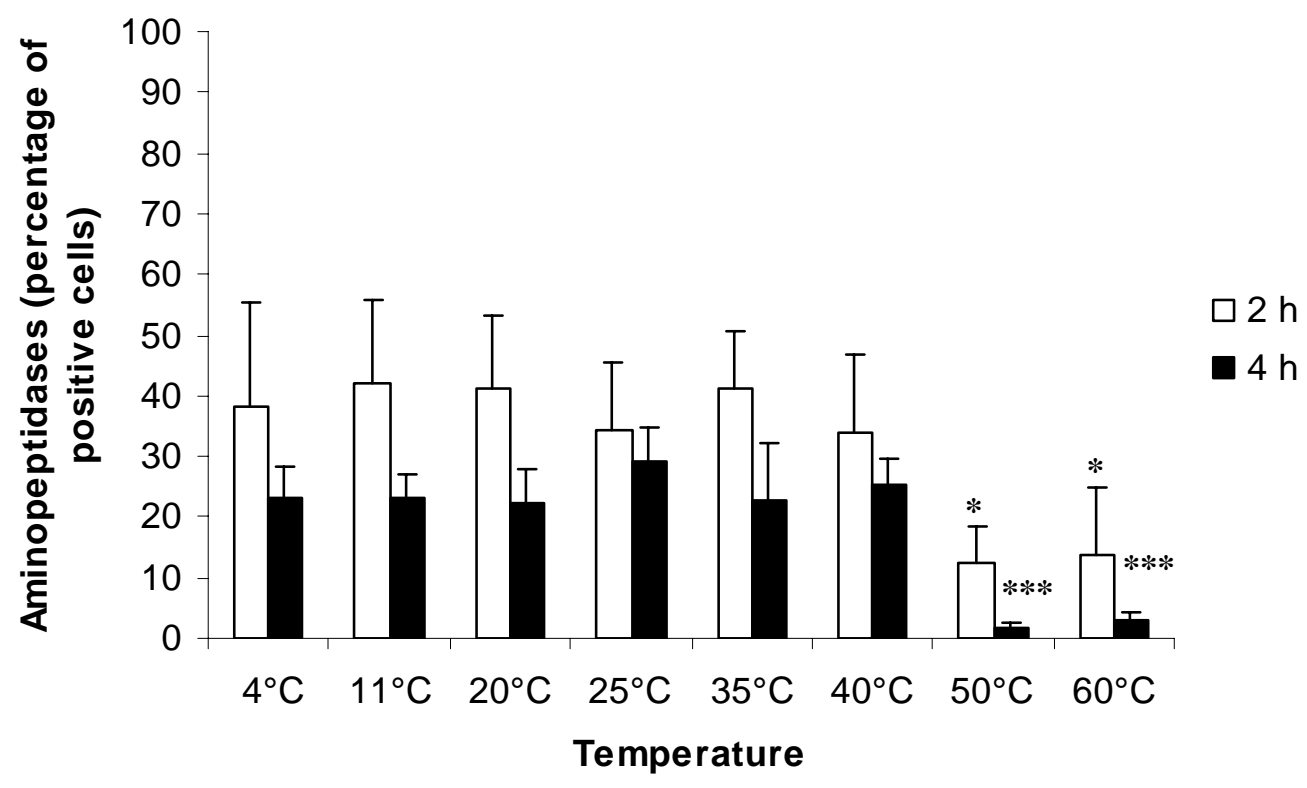

Figure 3: Percentage of positive cells for esterases of oysters evaluated by flow cytometry after an in vitro $2 \mathrm{~h}$ or $4 \mathrm{~h}$ incubation period at several temperatures $\left(4^{\circ} \mathrm{C}, 11^{\circ} \mathrm{C}, 20^{\circ} \mathrm{C}, 25^{\circ} \mathrm{C}, 35^{\circ} \mathrm{C}, 40^{\circ} \mathrm{C}, 50^{\circ} \mathrm{C}\right.$ and $\left.60^{\circ} \mathrm{C}\right)$. Values are mean of three replicates. Bars represent standard deviation. ${ }^{*}: \mathrm{p}<0.05,{ }^{* * *}: \mathrm{p}<0.001$.

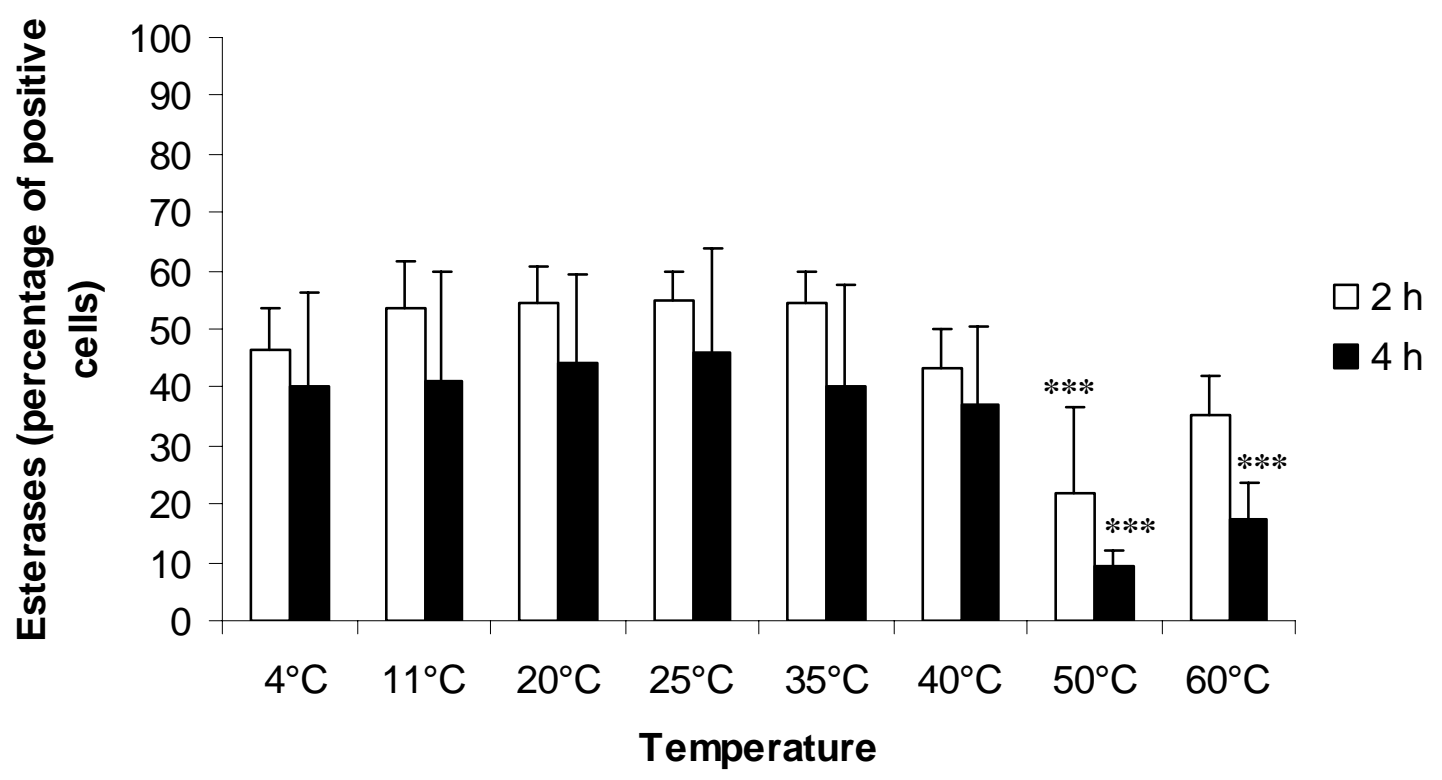




\section{$\underline{\text { In vivo experiments }}$}

Cell mortality significantly increased at $40^{\circ} \mathrm{C}, 50^{\circ} \mathrm{C}$ and $60^{\circ} \mathrm{C}$ (Figure $4, \mathrm{p}<0.001$ ). The percentage of esterase positive cells was significantly lower at $4^{\circ} \mathrm{C}$ and $60^{\circ} \mathrm{C}$ compared to other temperatures (Figure 4, $\mathrm{p}<0.001$ ) and phagocytosis activity decreased at $60^{\circ} \mathrm{C}$ (Figure 4, $\mathrm{p}<0.001)$.

Figure 4: Haemocyte mortality percentage, phagocytosis percentage and percentage of positive cells for esterases of oysters evaluated by flow cytometry after an in vivo $4 \mathrm{~h}$ incubation period at several temperatures $\left(4^{\circ} \mathrm{C}, 11^{\circ} \mathrm{C}, 20^{\circ} \mathrm{C}, 25^{\circ} \mathrm{C}, 35^{\circ} \mathrm{C}, 40^{\circ} \mathrm{C}, 50^{\circ} \mathrm{C}\right.$ and $\left.60^{\circ} \mathrm{C}\right)$. Values are mean of three replicates. Bars represent standard deviation. ${ }^{* *}$ : $\mathrm{p}<0.01,{ }^{* * *}: \mathrm{p}<0.001$.

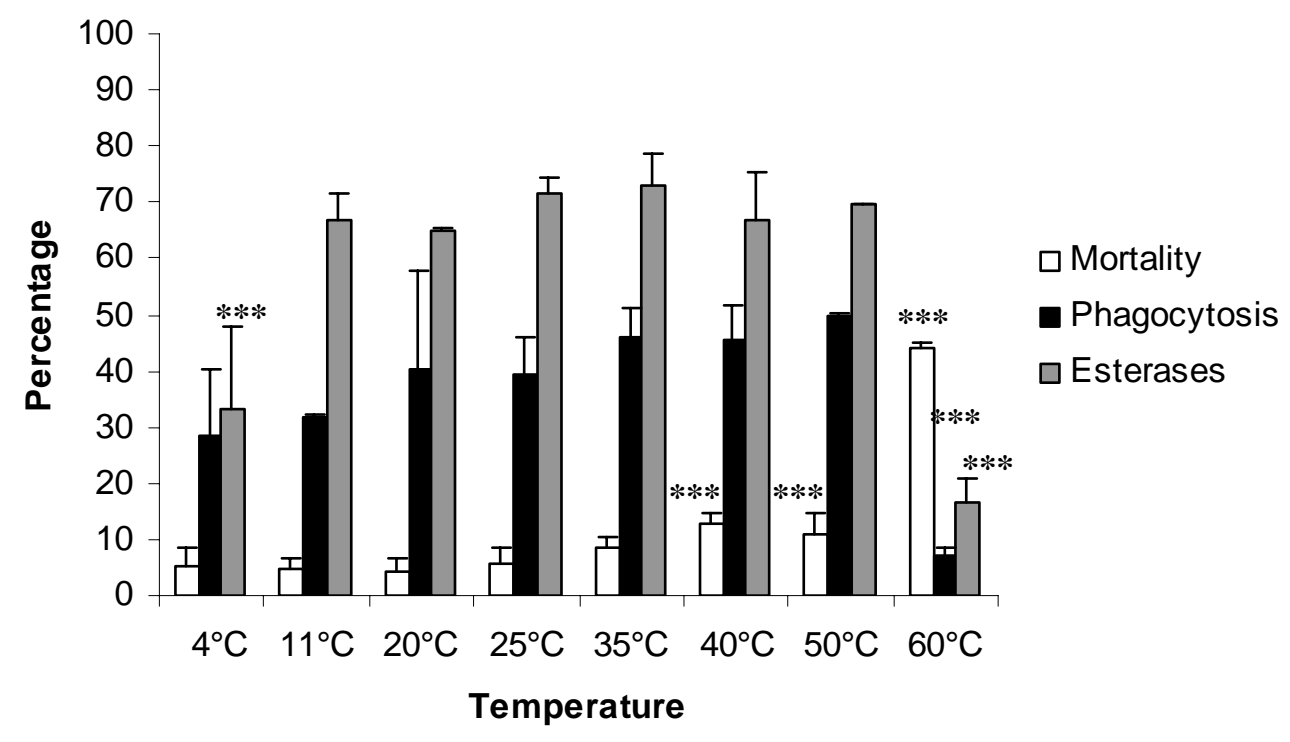

\section{Salinity}

\section{$\underline{\text { In vitro experiments }}$}

After a 2 h incubation period, cell mortality was significantly higher for lower salinities (6.5 $\%$, $3 \%$ and $0 \%$ ) (Figure 5, $\mathrm{p}<0.001$ ) in contrast with the percentage of esterase positive cells which was significantly lower (Figure 6, p<0.001). After a $18 \mathrm{~h}$ incubation period, mortality was significantly higher for $3 \%$ and $0 \%$ (Figure $5, \mathrm{p}<0.001$ ) and esterase 
percentage of positive cells was significantly lower for the same salinities (Figure 6, $\mathrm{p}<0.001)$.

Figure 5: Haemocyte mortality percentage of oysters evaluated by flow cytometry after an in vitro $2 \mathrm{~h}$ or $18 \mathrm{~h}$ incubation period at different salinities (32 \%o, $29 \%$, $25.5 \%$ \%, $22.5 \%$ o, 16 \%, $6.5 \%$, 3 \%o and $0 \%$ \%). Values are mean of four replicates. Bars represent standard deviation. ${ }^{* * *}: \mathrm{p}<0.001$.

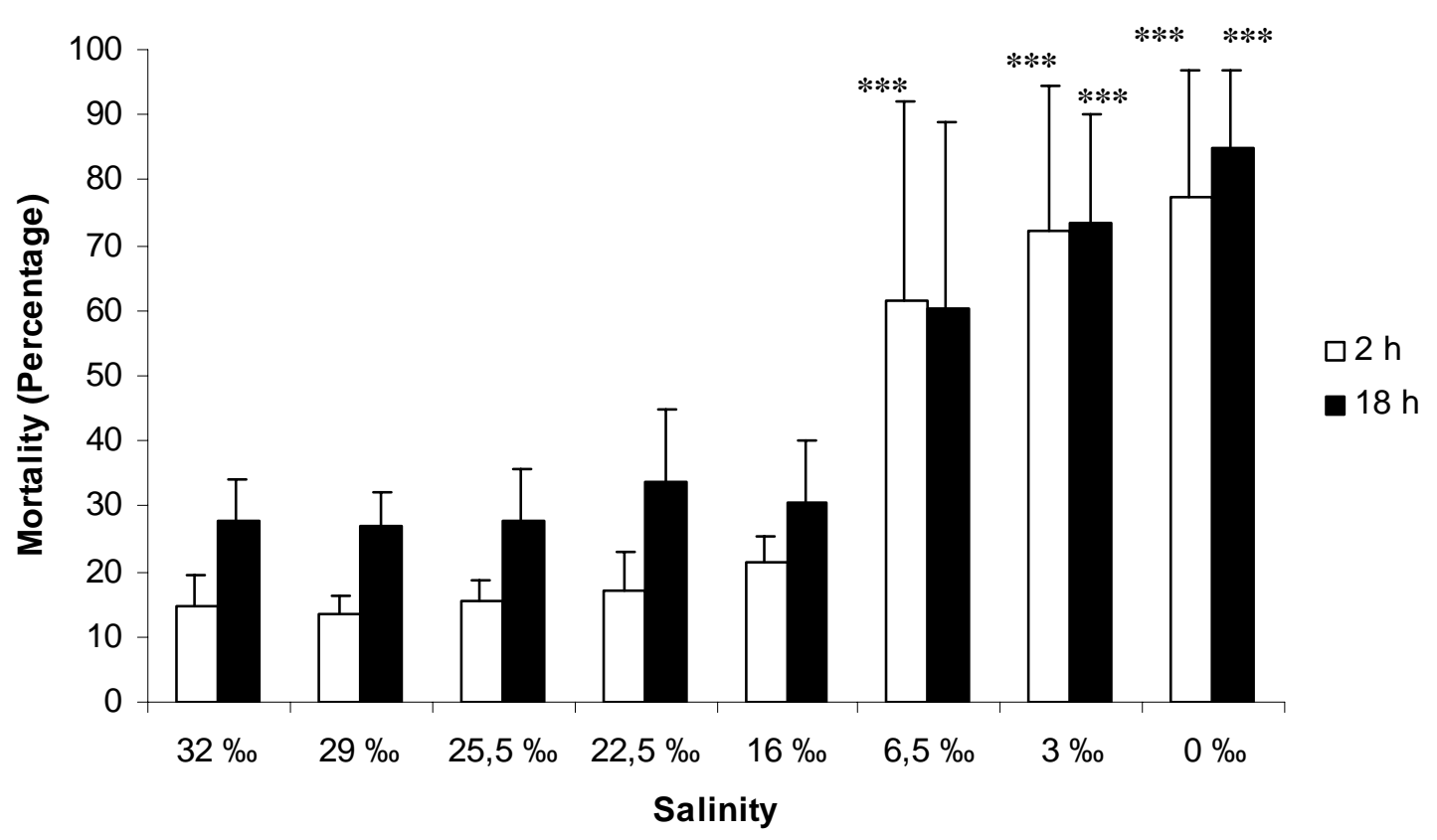

Figure 6: Percentage of positive cells for esterases of oysters evaluated by flow cytometry after an in vitro $2 \mathrm{~h}$ or $18 \mathrm{~h}$ incubation period at different salinities (32\%, $29 \%$, $25.5 \%$, $22.5 \%$, $16 \%$, $6.5 \%$, $3 \%$ and $0 \%$ ). Values are mean of four replicates. Bars represent standard deviation. $* * *: \mathrm{p}<0.001$.

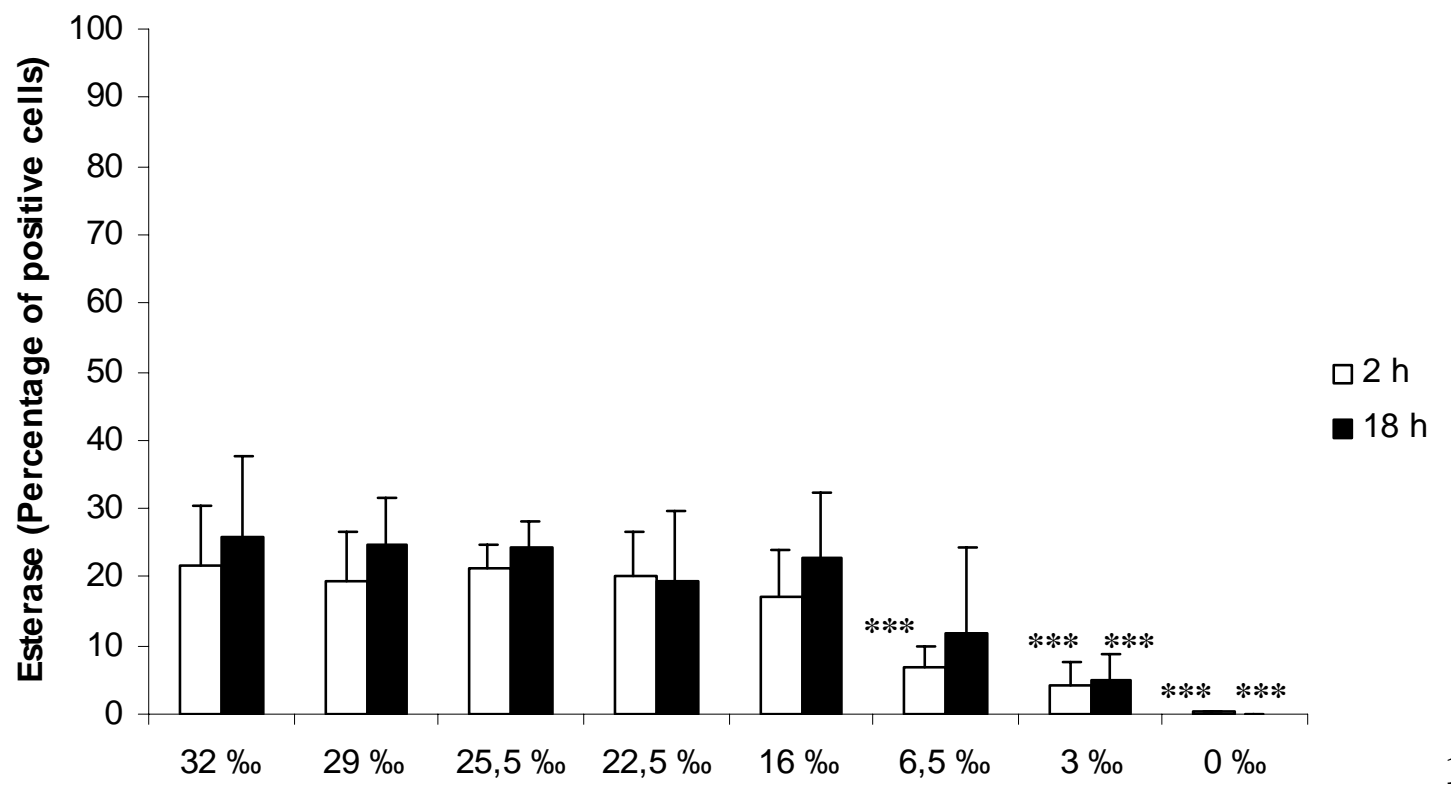

Salinity 


\section{$\underline{\text { In vivo experiments }}$}

No mortality was noted during the first experiment. After one day, phagocytosis activity was significantly lower in oysters placed in hyposalinity compared to the two other conditions (Figure 7, p<0.05). After three and seven days, phagocytosis activity was significantly lower in control oysters than in the two other conditions (Figure $7, \mathrm{p}<0.01$ ). Two-way analysis of variance showed that phagocytosis activity was significantly lower in control oysters than in oysters placed in hypersalinity $(\mathrm{p}<0.05)$. Cell mortality showed no variation in relation with salinity condition (data not showed).

In the second experiment, a high daily mortality was reported in hypo- and hypersalinity conditions (Figure 8). Oyster mortality appeared on day 3 for both conditions (15\% of mortality in hyposalinity, 25.9 \% of mortality in hypersalinity, Figure 8). Highest mortality levels were observed on day 6 (55.5\% of mortality in hyposalinity, $66.6 \%$ of mortality in hypersalinity, $0 \%$ of mortality in the control, Figure 8). Cell mortality and phagocytosis activity showed no effect related to salinity conditions during the first three days of experiment (data not shown).

Figure 7: Phagocytic activity of oysters evaluated by flow cytometry after an in vivo exposure to $15 \%$ (hyposalinity), $35 \%$ or $45 \%$ (hypersalinity) during seven days. Values are mean of three pools. Bars represent standard deviation. *: $\mathrm{p}<0.05$; **: $\mathrm{p}<0.01$.

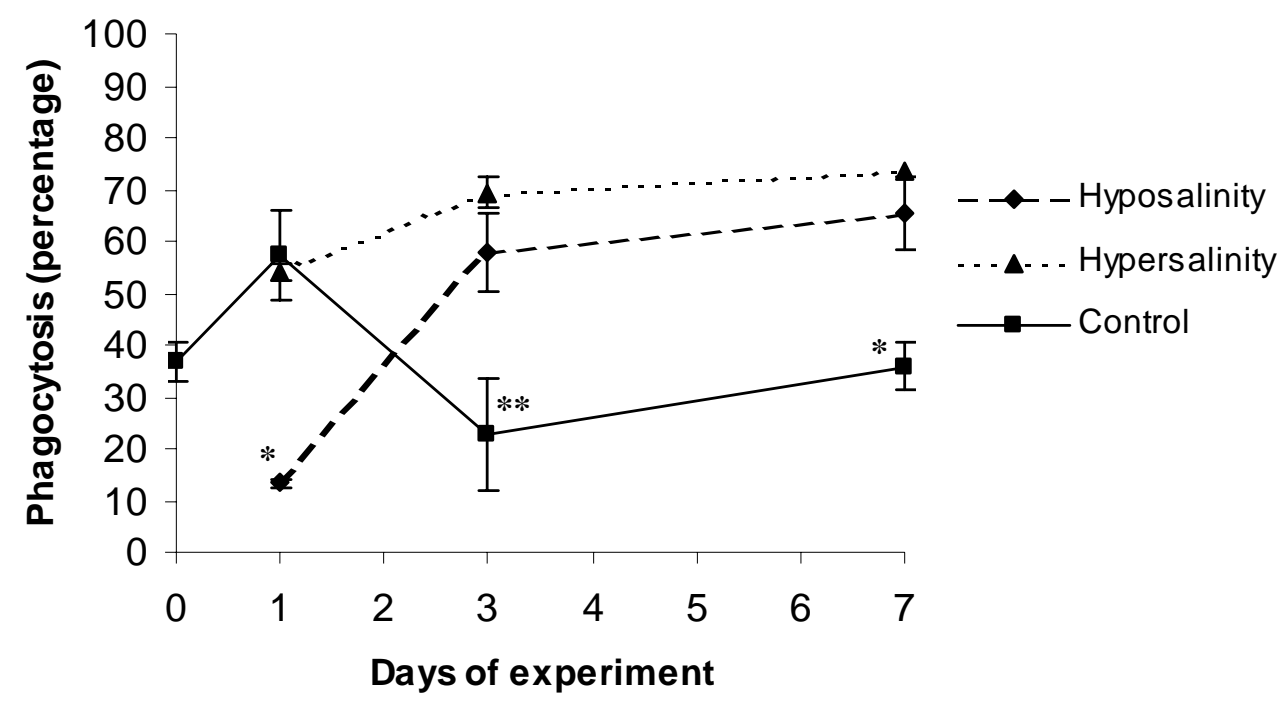


Figure 8: Daily mortality of oysters after an in vivo exposure to 5 \% (hyposalinity), $35 \%$ or $60 \%$ (hypersalinity) during seven days.

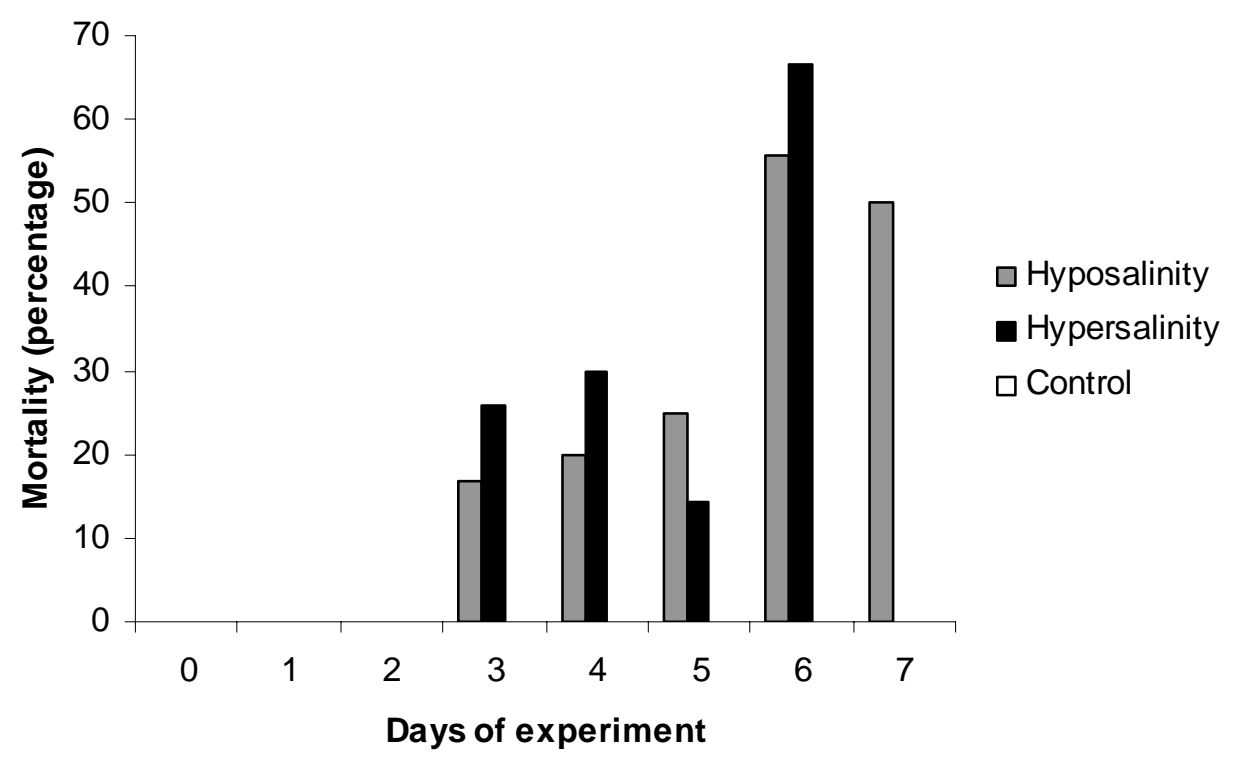

\section{Discussion}

In the present study, flow cytometry was used to demonstrate effects of two abiotic factors (temperature and salinity) on haemocyte parameters of the Pacific oyster, C. gigas. Flow cytometry has been shown to be an efficient tool for analysis of haemocytes in various mollusc species $(31,33-35)$. However, relatively few studies have used this tool for monitoring effect of temperature and salinity on haemocyte parameters (22, 36).

Pacific oysters were exposed to varying regimes of temperature and salinities in order to assess their sensitivity to abiotic factors including temperature and salinity. In in vitro experiments, we have demonstrated that while high temperatures induced hemocyte mortality, hemocytes can tolerate a temperature of $35^{\circ} \mathrm{C}$ without presenting any mortality. In contrast, a $4 \mathrm{~h}$ in vivo incubation period at $40^{\circ} \mathrm{C}, 50^{\circ} \mathrm{C}$ and $60^{\circ} \mathrm{C}$ increased cell mortality of oysters. Esterase activity was decreased at $4^{\circ} \mathrm{C}$ and $60^{\circ} \mathrm{C}$ and phagocytosis was decreased only at $60^{\circ} \mathrm{C}$. This was consistant with the decreased phagocytosis activity of Ostrea edulis haemocytes (25) and of $C$. virginica haemocytes $(22,36)$ as well as with the increased cell mortality of C. virginica haemocytes $(22,36)$ following temperature elevation. However, the 
decrease of enzymatic activities was predictable, as hemocytes presented mortality which is a consequence of morbidity. In Marennes-Oleron Bay (Charente-Maritime, France), 4 hours correspond to the time of exondation between low tide and high tide. The temperature in the field may often reach $40^{\circ} \mathrm{C}$ during summer period (37). Since oysters often encountered these extreme conditions, they may have become tolerant and thus the effect of high temperature may have been masked. In addition, oysters are thermo-conformers and our results confirm that oyster hemocytes can adapt to elevated temperatures.

In vitro decrease of salinity also induced an increase of cell mortality. However, as mentioned before, the decrease of enzymatic activities was predictable, as hemocytes presented mortality. Salinity variations also reduced haemocyte activities of $C$. virginica haemocytes in other studies $(24,27)$. However, oyster haemocytes are able to synthesize osmotic shock protein therefore protecting themselves from acute salinity variations (8). The relationships between in vitro measurements of haemocyte activities and the ability of marine bivalves to develop accurate defence in the field have not been established. In vitro measurements do not represent in vivo or in situ conditions (25).

In vivo experiments involving salinity were also conducted. In the first experiment, phagocytosis activity was enhanced at high both salinity (45 \%o) and low salinity (15 \%o). Another study reported a decrease of phagocytosis in Ruditapes philippinarum associated with an increase of salinity (38). These results indicate that salinity may modulate phagocytic activity. In the second experiment, oysters were reared at $5 \%$ and $60 \%$, and both conditions induced high mortality. However, those values are distant from the range of salinity reported in Marennes-Oleron Bay (21-34 \%o), where C. gigas are reared (37). Oysters may not be able to acclimate to high salinities. However, a part of oysters are reared in "claires" (oyster pounds), a confined zone, where salinity may decrease to $15 \%$ after rainfalls (Soletchnik, personal communication). 
C. gigas have been successfully introduced in many countries over the world since the 1950s (1, 39). We can therefore conclude that this species is naturally subjected to important variations of environmental conditions and can acclimate to them. Moreover, our results clearly demonstrated that only extreme values of temperature and salinity can modify haemocyte activites of $C$. gigas. Haemocytes are apparently resistant cells because only high values of temperature and salinity kill them. This phenomenon has already been observed with pollutant exposure: only high concentrations of mercury chloride were able to kill haemocytes after $4 \mathrm{~h}$ of in vitro contact (40).

These results could lead us to study possible interactions between the effects of abiotic factors and pollutants or susceptibility to infections. Most of the studies conducted on abiotic factors including temperature and salinity on bivalve defence functions pointed on to the relationships between abiotic factors and diseases. The virulence of infectious agents in the field has been correlated with high salinities and temperatures (41). Prevalence and intensity of Perkinsus marinus in C. virginica is positively correlated to salinity (29) and to temperature (42), suggesting that parasite virulence may be increased or oyster resistance may be decreased at high salinities (43) and high temperatures.

Viral infection may also be influenced by temperature and salinity. In the hard clam, Meretrix lusoria, birnavirus has proved to be more pathogen to young stages when a rapid increase of water temperature occurs (44). Moreover, herpes virus affecting the Pacific oyster, C. gigas, may exist as a latent form or low productive infection and temperature elevation can declare the disease into the whole organism for larvae and spat $(45,46)$.

In vivo acute variations of temperature and salinity increase could temporarily affect the ability of shellfish haemocytes to resist foreign invasion (25). Temperature and salinity appear to be key factors modulating the host immune defence in invertebrates and influences the 
severity of disease in several bivalve species, particularly during young stages (47). Their role in massive mortalities affecting different invertebrate species of economic interest must be taken into account. The interactions between temperature, salinity, pollutants and pathogens, added with all other environmental factors ( $\mathrm{pH}$, dissolved oxygen) could represent scraps of explanation of summer mortality phenomenon in $C$. gigas. In this context, experiments studying relationships between modulation of abiotic factors and infectious agents (including bacteria or OsHV-1) could be conducted in the future.

\section{Acknowledgements}

The authors are thankful to P. Goulletquer for allowing the work at the IFREMER station in La Tremblade (Charente-Maritime, France). Thanks to Dr Thierry Burgeot for his advices. The authors are grateful to Dr Sylvie St-Jean (Fisheries and Oceans Canada, Burlington, Ontario, Canada) for improving the English of this manuscript. This research was supported in part by the Poitou-Charentes Region. 


\section{References}

(1) Grizel, H. \& Heral, M. (1991). Introduction into France of the Japanese oyster (Crassostrea gigas). The ICES Journal of Marine Science 47, 399-403.

(2) Cheney, D.P., MacDonald, B.F. \& Elston, R.A. (2000). Summer mortality of Pacific oysters, Crassostrea gigas (Thunberg): Initial findings on multiple environmental stressors in Puget Sound, Washington, 1998. Journal of Shellfish Research 19, 353-359.

(3) Glude, J.B. (1974). A summary report of Pacific Coast oyster mortality investigations 1965-1972. In: (Proceedings of the Third U.S.-Japan Meeting on Aquaculture at Tokyo, eds) pp. 28. Tokyo:

(4) Koganezawa, A. (1974). Present status of studies on the mass mortality of cultured oysters in Japan and its prevention. In: (Proceedings of the Third U.S.-Japan Meeting on Aquaculture at Tokyo, eds) pp. 29-34. Tokyo:

(5) Goulletquer, P., Soletchnik, P., Le Moine, O., Razet, D., Geairon, P., Faury, N. \& Taillade, S. (1998). Summer mortality of the Pacific cupped oyster Crassostrea gigas in the Bay of Marennes-Oleron (France). ICES Mariculture Committee CM, Copenhagen.

(6) Livingstone, D.R. (1998). The fate of organic xenobiotics in aquatic ecosystems: quantitative and qualitative differences in biotransformation by invertebrates and fish. Comparative Biochemistry and Physiology - Part A: Molecular \& Integrative Physiology 120, 43-49.

(7) Shumway, S.E. (1977). Effect of salinity fluctuation on the osmotic pressure and $\mathrm{Na}+$, $\mathrm{Ca} 2+$ and Mg2+ ion concentrations in the hemolymph of bivalve molluscs. Marine Biology 41, 153-177.

(8) Tirard, C.T., Grossfeld, R.M., Levine, J.F. \& Kennedy-Stoskopf, S. (1997). Effect of osmotic shock on protein synthesis of oyster hemocytes in vitro. Comparative Biochemistry and Physiology - Part A: Molecular \& Integrative Physiology 116, 43-49. 
(9) Cheng, T.C. \& Combes, C. (1990). Influence of environmental factors on the invasion of molluscs by parasites: with special reference to Europe. In: Biological invasions in Europe and the Mediterranean Basin (F.d. Castri, A.J. Hansen \& M. Debussche, eds) pp. 307-332. Dordrecht: Kluwer Academic Publishers.

(10) Cheng, T.C. (1981). Bivalves. In: Invertebrate Blood Cells I (N.A. Ratcliffe \& A.F. Rowley, eds) pp. 233-299. London: Academic Press.

(11) Fisher, S.W. (1986). Structure and functions of oyster hemocytes. In: Immunity in Invertebrates (M. Brehélin, eds) pp. 25-35. Berlin Heidelberg: Springer-Vrelag.

(12) Cheng, T.C. (1996). Hemocytes: forms and functions. In: The eastern oyster Crassostrea virginica (V.S. Kennedy, R.I.E. Newell \& F. Eble, eds) pp. 299-333. Maryland Sea Grant College, College Park.

(13) Pipe, R.K. (1992). Generation of reactive oxygen metabolites by the haemocytes of the mussel Mytilus edulis. Developmental \& Comparative Immunology 16, 111-122.

(14) Carballal, M.J., Lopez, C., Azevedo, C. \& Villalba, A. (1997). Enzymes involved in defense functions of hemocytes of Mussel Mytilus galloprovincialis. Journal of Invertebrate Pathology 70, 96-105.

(15) Cheng, T.C. \& Rodrick, G.E. (1975). Lysosomal and other enzymes in the hemolymph of Crassostrea virginica and Mercenaria mercenaria. Comparative Biochemistry and Physiology, part B 52, 443-447.

(16) Moore, C.A. \& Gelder, S.R. (1985). Demonstration of lysosomal enzymes in hemocytes of Mercenaria mercenaria (Mollusca : Bivalvia). Transactions of the American Microscopy Society 104, 242-249.

(17) Torreilles, J., Guerin, M.C. \& Roch, P. (1997). Peroxidase-release associated with phagocytosis in Mytilus galloprovincialis haemocytes. Developmental \& Comparative Immunology 21, 267-275. 
(18) Gelder, S.R. \& Moore, C.A. (1986). Cytochemical demonstration of several enzymes associated with phagosomal processing of foreign material within hemocytes of Mercenaria mercenaria. Transactions of the American Microscopy Society 105, 51-58.

(19) Beckmann, N., Morse, M.P. \& Moore, C.M. (1992). Comparative study of phagocytosis in normal and diseased hemocytes of the bivalve mollusc Mya arenaria. Journal of Invertebrate Pathology 59, 124-132.

(20) Alvarez, M.R., Friedl, F.E., Johnson, J.S. \& Hinsch, G.W. (1989). Factors affecting in vitro phagocytosis by oyster hemocytes. Journal of Invertebrate Pathology 54, 233-241.

(21) Cheng, W. \& Chen, J.C. (2000). Effects of pH, temperature and salinity on immune parameters of the freshwater prawn Macrobrachium rosenbergii. Fish \& Shellfish Immunology 10, 387-391.

(22) Hegaret, H., Wikfors, G.H. \& Soudant, P. (2003). Flow cytometric analysis of haemocytes from eastern oysters, Crassostrea virginica, subjected to a sudden temperature elevation II. Haemocyte functions: aggregation, viability, phagocytosis, and respiratory burst. Journal of Experimental Marine Biology and Ecology 293, 249-265.

(23) Robillard, S., Beauchamp, G. \& Laulier, M. (2003). The role of abiotic factors and pesticide levels on enzymatic activity in the freshwater mussel Anodonta cygnea at three different exposure sites. Comparative Biochemistry and Physiology - Part C: Toxicology \& Pharmacology 135, 49-59.

(24) Fisher, S.W. (1988). Environmental influence on host response: environmental influence on bivalve hemocyte function. American Fisheries Society Special Publication 18, 225-237.

(25) Fisher, W.S., Auffret, M. \& Balouet, G. (1987). Response of European flat oyster (Ostrea edulis) hemocytes to acute salinity and temperature changes. Aquaculture 67, 179190. 
(26) Auffret, M. \& Oubella, R. (1994). Cytometric parameters of bivalve molluscs : effect of environmental factors. In: Modulators of fish immune responses (J.S. Stolen \& T.C. Fletcher, eds) pp. 23-32. Fair Haven, NJ, USA: SOS Publication.

(27) Fisher, W.S. \& Newell, R.I.E. (1986). Salinity effects on the activity of granular hemocytes of American oysters, Crassostrea virginica. Biological Bulletin, Marine Biological Laboratory, Woods Hole 170, 122-134.

(28) Chu, F.-L.E. \& La Peyre, J.F. (1993). Perkinsus marinus susceptibility and defenserelated activities in eastern oysters Crassostrea virginica: Temperature effects. Diseases of Aquatic Organisms 16, 223-234.

(29) Chu, F.-L.E., La Peyre, J.F. \& Burreson, C.S. (1993). Perkinsus marinus infection and potential defense-related activities in eastern oysters, Crassostrea virginica: Salinity effects. Journal of Invertebrate Pathology 62, 226-232.

(30) Goedken, M. \& De Guise, S. (2004). Flow cytometry as a tool to quantify oyster defence mechanisms. Fish \& Shellfish Immunology 16, 539-552.

(31) Xue, Q.G., Renault, T. \& Chilmonczyk, S. (2001). Flow cytometric assessment of haemocyte sub-populations in the European flat oyster, Ostrea edulis, haemolymph. Fish \& Shellfish Immunology 11, 557-567.

(32) Sauve, S., Hendawi, M., Brousseau, P. \& Fournier, M. (2002). Phagocytic response of terrestrial and aquatic invertebrates following in vitro exposure to trace elements. Ecotoxicology and Environmental Safety 52, 21-29.

(33) Fournier, M., Pellerin, J., Clermont, Y., Morin, Y. \& Brousseau, P. (2001). Effects of in vivo exposure of Mya arenaria to organic and inorganic mercury on phagocytic activity of hemocytes. Toxicology 161, 201-211. 
(34) Gagnaire, B., Renault, T., Bouilly, K., Lapegue, S. \& Thomas-Guyon, H. (2003). Study of atrazine effects on Pacific oyster, Crassostrea gigas, haemocytes. Current Pharmaceutical Design 9, 193-199.

(35) Fisher, S.W. \& Ford, S.E. (1988). Flow cytometry: a tool for cell research in bivalve pathology. American Fisheries Society Special Publication 18, 286-291.

(36) Hegaret, H., Wikfors, G.H. \& Soudant, P. (2003). Flow-cytometric analysis of haemocytes from eastern oysters, Crassostrea virginica, subjected to a sudden temperature elevation I. Haemocyte types and morphology. Journal of Experimental Marine Biology and Ecology 293, 237-248.

(37) Soletchnik, P., Faury, N., Razet, D. \& Goulletquer, P. (1998). Hydrobiology of the Marennes-Oleron Bay. Seasonal indices and analysis of trends from 1978 to 1995. Hydrobiologia 386, no.

(38) Reid, H.I., Soudant, P., Lambert, C., Paillard, C. \& Birkbeck, T.H. (2003). Salinity effects on immune parameters of Ruditapes philippinarum challenged with Vibrio tapetis. Diseases of Aquatic Organisms 56, 249-258.

(39) Grizel, H. (1996). Quelques exemples d'introduction et de transferts de mollusques. Revue Scientifique et Technique de l'Office International des Epizooties 15, 401-408.

(40) Gagnaire, B., Thomas-Guyon, H. \& Renault, T. (2004). In vitro effects of cadmium and mercury on Pacific oyster, Crassostrea gigas (Thunberg), haemocytes. Fish \& Shellfish Immunology 16, 501-512.

(41) Chu, F.-L.E. \& Hale, R.C. (1994). Relationship between pollution and susceptibility to infectious disease in the eastern oyster, Crassostrea virginica. Marine Environmental Research 38, 243-256. 
(42) Chu, F.-L.E. \& La Peyre, J.F. (1993). Perkinsus marinus susceptibility and defenserelated activities in eastern oysters Crassostrea virginica : Temperature effects. Diseases of Aquatic Organisms 16, 223-234.

(43) Anderson, R.S., Burreson, E.M. \& Paynter, K.T. (1995). Defense Responses of Hemocytes Withdrawn from Crassostrea virginica Infected with Perkinsus marinus. Journal of Invertebrate Pathology 66, 82-89.

(44) Chou, H.-Y., Li, H.-J. \& Lo, C.-F. (1994). Pathogenicity of a birnavirus to hard clam (Meretrix lusoria) and effect of temperature stress on its virulence. Fish Pathology 29, 171175.

(45) Le Deuff, R.M., Renault, T. \& Gerard, A. (1996). Effects of temperature on herpes-like virus detection among hatchery-reared larval Pacific oyster Crassostrea gigas. Diseases of Aquatic Organisms 24, 149-157.

(46) Renault, T., Le Deuff, R.M., Cochennec, N. \& Maffrat, P. (1994). Herpesviruses associated with mortalities among Pacific oyster, Crassostrea gigas, in France - comparative study. Revue de Médecine Vétérinaire 145, 735-742.

(47) Paillard, C., Allam, B. \& Oubella, R. (2004). Effect of temperature on defense parameters in Manila clam Ruditapes philippinarum challenged with Vibrio tapetis. Diseases of Aquatic Organisms 59, 249-262. 